\title{
PREVALENCE OF Trypanosoma cruzi AND Leishmania chagasi INFECTION AND RISK FACTORS IN A COLOMBIAN INDIGENOUS POPULATION
}

\author{
Augusto CORREDOR ARJONA(1), Carlos Arturo ALVAREZ MORENO(1,4), Carlos Alberto AGUDELO(1), Martha BUENO(3), Myriam Consuelo LÓPEZ(1), Elvia \\ CÁCERES(1), Patricia REYES(1), Sofia DUQUE BELTRAN(2), Luis Eduardo GÜALDRON(2) \& Maria Mercedes SANTACRUZ(2)
}

\begin{abstract}
SUMMARY
This study was carried out in order to obtain base-line data concerning the epidemiology of American Visceral Leishmaniasis and Chagas' Disease in an indigenous population with whom the government is starting a dwelling improvement programme. Information was collected from 242 dwellings (1,440 people), by means of house to house interviews about socio-economic and environmental factors associated with Leishmania chagasi and Trypanosoma cruzi transmission risk. A leishmanin skin test was applied to 385 people and 454 blood samples were collected on filter paper in order to detect L. chagasi antibodies by ELISA and IFAT and T. cruzi antibodies by ELISA.

T. cruzi seroprevalence was $8.7 \%$ by ELISA, L. chagasi was $4.6 \%$ and $5.1 \%$ by IFAT and ELISA, respectively. ELISA sensitivity and specificity for L. chagasi antibodies were $57 \%$ and $97.5 \%$ respectively, as compared to the IFAT. Leishmanin skin test positivity was $19 \%$. L. chagasi infection prevalence, being defined as a positive result in the three-immunodiagnostic tests, was $17.1 \%$. Additionally, $2.7 \%$ of the population studied was positive to both L. chagasi and T. cruzi, showing a possible cross-reaction. L. chagasi and T. cruzi seropositivity increased with age, while no association with gender was observed. Age $(p<0.007)$, number of inhabitants $(p<0.05)$, floor material $(\mathrm{p}<0.03)$ and recognition of vector $(\mathrm{p}<0.01)$ were associated with $T$. cruzi infection, whilst age $(\mathrm{p}<0.007)$ and dwelling improvement $(\mathrm{p}<0.02)$ were associated with L. chagasi infection. It is necessary to evaluate the long-term impact of the dwelling improvement programme on these parasitic infections in this community.
\end{abstract}

KEYWORDS: Visceral leishmaniasis; Chagas' disease; Seroprevalence; Colombia.

\section{INTRODUCTION}

The Tripanosomatidae which affect man in America are from the Leishmania and Trypanosoma genera. The first combines different leishmaniasis species, within which Leishmania chagasi is found. The American Visceral Leishmaniasis' (AVL) causative agent; within the second is found Trypanosoma cruzi, the causative agent of American trypanosomiasis. These parasitoses occupy shared ecological niches ${ }^{31}$ in many parts of America, from the south of the United States to Argentina, which allow simultaneous evaluation of the two entities.

In Colombia, AVL was described for the first time in 1944 by GAST GALVIS in a patient from the State of Santander ${ }^{16}$. After notification of this AVL case, almost 20 years (1960) passed until two new cases were reported ${ }^{17}$. From 1981 onwards, more than 600 new cases have been recorded, which can be explained by amongst other aspects, the suspension of DDT spraying in L. chagasi synanthropic foci and an improvement in the diagnosis and reporting of the disease ${ }^{23}$. The Tolima department is the region of the country where most visceral leishmaniasis cases have been registered since $1981 ; 37.3 \%$ corresponded to the municipality of Coyaima, which makes it one of the country's most important foci ${ }^{5}$.

On the other hand, the estimated figures for human infection with $T$. cruzi in Colombia oscillate between 1,200,000 and 1,700,000 inhabitants and some 40,000 new cases occur every year, principally in regions situated below 2,000 metres above sea-level and which coincide with the distribution of the principal vector in Colombia, Rhodnius prolixus, in the departments of Guajira, Cesar, Santander, Boyacá, Arauca, Casanare, Cundinamarca, Tolima, Meta, Huila, Caquetá, Bolívar and Caldas ${ }^{10,11}$. Some blood-bank seroprevalence studies from endemic zones in the departments of Santander, Norte de Santander, Tolima, Boyaca, Cundinamarca, Meta, Huila, Guajira, Cesar, Arauca, Casanare and Caqueta, show levels oscillating between $3 \%$ and $6 \%{ }^{7,18,19}$.

In the municipality of Coyaima, $R$. prolixus was found in habitations and to be infected with T. cruzi and T. rangeli ${ }^{10}$. Some previous serological surveys revealed active trypanosome transmission ${ }^{24}$. However, until the present, no studies have been initiated to allow the magnitude of American trypanosomiasis in this region to be established.

(1) Public and Tropical Health Department, Instituto de Salud en el Trópico, Universidad Nacional, Bogotá, Colombia.

(2) Parasitology Laboratory, Instituto Nacional de Salud, Bogotá, Colombia

(3) Biology Department, Facultad de Ciencias, Universidad Nacional, Bogotá, Colombia.

(4) Infectious Diseases Unit, Internal Medicine Department, Universidad Nacional, Bogotá, Colombia.

Correspondence to: Dr. Carlos Arturo Alvarez, Instituto de Salud en el Trópico, Of. 318, Ciudad Universitaria, Bogotá, Colombia.

Email: calvarem@hotmail.com; calvarem@bacata.usc.unal.edu.co 


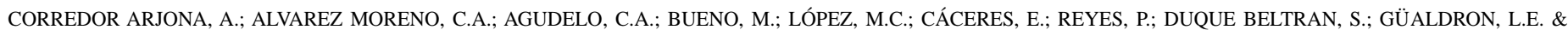
SANTACRUZ, M.M. - Prevalence of Trypanosoma cruzi and Leishmania chagasi infection and risk factors in a Colombian indigenous population. Rev. Inst. Med. trop. S. Paulo, 41(4): 229-234,1999.

According to the characteristics of the region in question, it is necessary to establish the dynamics of the two entities' transmission, by means of the evaluation of the different ecological, socio-economic and cultural factors, which influence its transmission chain. This study was intended to learn about $T$. cruzi and $L$. chagasi infection prevalence and their possible relationship with reservoirs, vectors and associated risk factors. Given that these parasitoses are determined, for the greater part, by housing conditions, the study allowed base-line information to be obtained concerning epidemiological aspects in order to evaluate the impact of a housing modification and improvement programme on the prevalence of these diseases. This programme was initiated by the government due to the 1991 epidemic in this municipality and consisted of peridomiciliary changes, latrine, farmyard and kitchen construction and domestic changes such as modifications to walls, roof and/or floor.

\section{MATERIALS AND METHODS}

The study was carried out in the municipality of Coyaima, located in the Tolima department, covering an area of $667 \mathrm{~km}^{2}$. The town centre is located at $03^{\circ} 48^{\prime} 09^{\prime \prime}$ latitude North and 75 $11^{\prime}$ '54' longitude West and $350 \mathrm{~m}$ altitude (Fig. 1) ${ }^{21}$. The average temperature is $28.2^{\circ} \mathrm{C}$, with an annual rainfall of $1,502 \mathrm{~mm}$. The surrounding land is distributed between thermic, hot and mild levels. Economic activities of greatest importance are agriculture, dairy-farming and mining. Principal crops are coffee, sesame seeds, maize and millo. Precious metal, lime and barita mines are being worked.

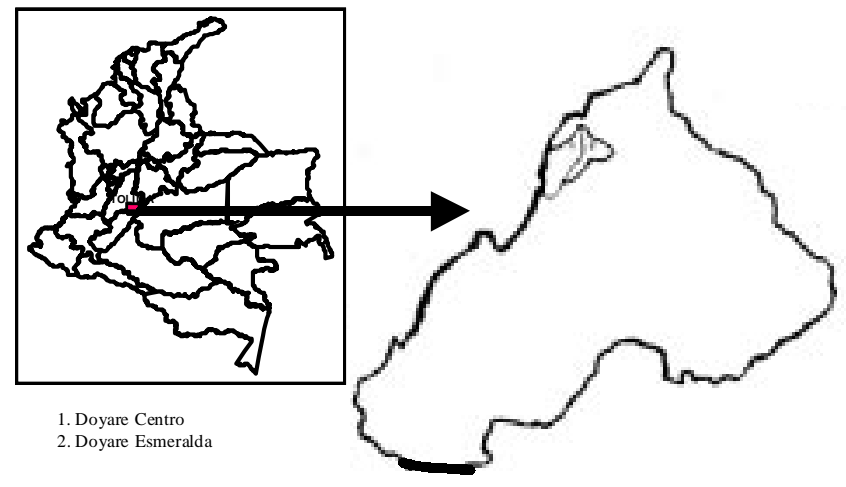

Fig. 1 - Municipality of Coyaima, Tolima located in the centre of the country.

According to the 1993 census, Coyaima has a population of approximately 23,303 inhabitants, $90 \%$ of whom belong to the Indian community and live in the rural zone. $84 \%$ of the inhabitants have unsatisfactory basic necessities and levels of illiteracy were $24.2 \%$ for men and $32.6 \%$ for women ${ }^{12}$.

The study area was established in the following way:

During the 1977-1995 period, the Coyaima hospital attended 165 parasitologically confirmed cases of visceral leishmaniasis. From this information, the study area was established; the two localities from which the greatest number of cases came and in which the housing modification programme had been initiated at least two years before, due to the cholera epidemic, being selected. The localities of Doyare Centro and Doyare Esmeralda were thus chosen.
In the chosen localities, 242 homes (100\% of the total) were surveyed during 1995-1996, concerning risk, socio-economic and environmental factors associated with $L$. chagasi and $T$. cruzi transmission such as: number of years as householders, overcrowding, type of housing, roof, floor and wall materials, public services to the housing, prevention measures taken for vector control such as spraying and use of mosquitonetting, vector presence and identification, reservoir presence, possession of animals and housing modification.

The survey revealed a population of 1,440 people of indigenous ethnology, with equal gender proportions (sexes) and showed that of the 242 homes, 124 had been included in the housing modification and improvement programme.

The procedure which was applied will be described next, previous written consent having been obtained from the 538 people who made up the sample. The sample presented the same age and gender distribution as the original population.

The Montenegro test was applied to the whole sample, reading of which was only possible for 385 people, 48 hours after inoculation, individuals with $\geq 4 \mathrm{~mm}$ indurations being considered to be positive. The test was made with $L$. chagasi promastigote soluble extract, containing $25 \mu \mathrm{g} / \mathrm{ml}$ parasite protein, manufactured at the Instituto Nacional de Salud according to previously described methodology ${ }^{9}$.

Blood samples were taken from 454 people, from the sample's total 538, on Whattman \#3 filter paper on which tests to determine T. cruzi and $L$. chagasi antibodies were carried out utilizing ELISA and IFAT (Indirect Fluorescence Antibody Test) techniques, according to previously described methodology. IFAT was carried out following CAMARGO DE SOUZA \& CAMARGO ${ }^{14}$ and CORREDOR \& LÓPEZ's procedures ${ }^{8}$. The ELISA was made according to BARTLETT et $a l .{ }^{4}$, using $T$. cruzi and $L$. chagasi soluble antigen in $0.75 \mu \mathrm{g} / \mathrm{ml}$ and $500 \mu \mathrm{g} / \mathrm{ml}$ concentrations respectively and 1:1,000 in $T$. cruzi and 1:50 in L. chagasi. Optical densities greater than 0.4 and 0.5 were considered to be ELISA positive for T. cruzi and L. chagasi. Titres equal to or greater than 1:32 for the IFAT test were considered to be positive for $L$. chagasi. All individuals who proved to be positive, in any of the tests, were submitted to a clinical examination looking for possible signs of Chagas' disease or AVL.

The search for AVL infection in domestic reservoirs was carried out on 22 dogs belonging to houses where seropositive individuals or those reactive to leishmanina for $L$. chagasi were found. These dogs were evaluated by clinical examination and direct smear of the popliteal ganglion haemolymph.

Phlebotomine captures were undertaken for 10 days, inside the housing's living space as well as in the peridomiciliary area where positive cases were registered. Forest samples were also taken from form-wooded areas close to the housing. These samples were taken during dawn and nightfall hours (approximately 8 hours/day/person) during the month of July, using automatic and manual aspirators on human and animal bait (chicken, pigs, cattle and dogs). Captured Phlebotomines were stored in $70 \%$ alcohol and information concerning day, hour and capture site were noted. The insects so collected were identified in the Universidad 


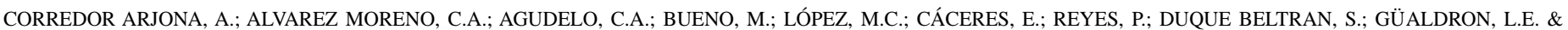

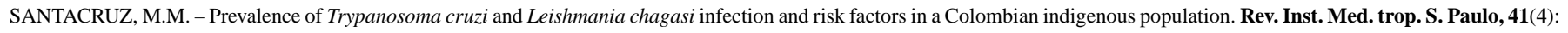
229-234,1999.

\section{Table 1}

L. chagasi and T. cruzi infection positivity in an Indigenous Community. Coyaima. 1996

\begin{tabular}{|c|c|c|c|c|c|c|c|c|}
\hline & \multicolumn{6}{|c|}{$\begin{array}{l}\text { L. chagasi } \\
\text { INFECTION }\end{array}$} & \multirow{2}{*}{\multicolumn{2}{|c|}{$\begin{array}{c}\text { T. } \text { cruzi } \\
\text { INFECTION } \\
\text { ELISA }\end{array}$}} \\
\hline & \multicolumn{2}{|c|}{ ELISA } & \multicolumn{2}{|c|}{ IFAT } & \multicolumn{2}{|c|}{$\begin{array}{c}\text { Montenegro Skin } \\
\text { Test }\end{array}$} & & \\
\hline & $\#$ & $\%$ & \# & $\%$ & \# & $\%$ & \# & $\%$ \\
\hline POSITIVE & 23 & 5.1 & 21 & 4.6 & 73 & 19.0 & 39 & 8.7 \\
\hline NEGATIVE & 431 & 94.9 & 433 & 95.4 & 312 & 81.0 & 409 & 91.3 \\
\hline TOTAL & 454 & 100 & 454 & 100 & 385 & 100 & 448 & 100 \\
\hline
\end{tabular}

Nacional de Colombia Biology laboratories. Dissection was not used in the search for L. chagasi natural infection nor was housing inspected in the search for triatomine bugs.

For risk factor analysis, a house was considered positive when one or more individuals living in it were positive by any of the tests performed.

The proportions were compared by $\mathrm{X}^{2}$ test and Fischer test when necessary. The EPIINFO programme version $6.04{ }^{13}$ was used to make these tests.

\section{RESULTS}

\section{Seroprevalence}

The ELISA test was positive in $8.7 \%$ for $T$. cruzi antibodies. For $L$. chagasi, ELISA and IFAT positivity was $5.1 \%$ and $4.6 \%$ respectively. Montenegro Skin Test (MST) was $19.0 \%$ (Table 1). If all individuals positive for any one of the three immunodiagnostic methods are considered to be L. chagasi positive cases, then positivity was $23.3 \%$.

The positivity of the MST (reactive individuals over population examined) showed a statistically significant progressive increase with age $(\mathrm{p}<0.05)$ (Figure 2$)$.

In the case of $T$. cruzi infection as evaluated by ELISA, positivity increased with age and then decreased in the 40-49 year old group (Figure 3). L. chagasi antibody detection was carried out by ELISA as well as IFAT, finding a progressive increase with age, however a diminution

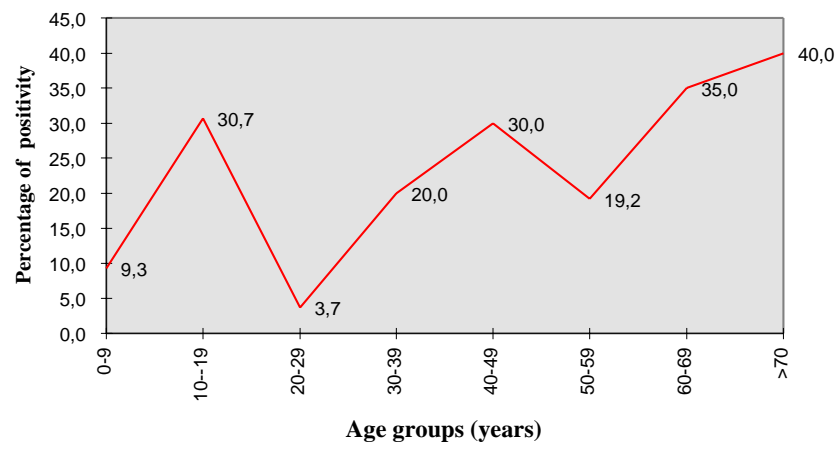

Fig. 2 - Montenegro skin test by age groups. Coyaima. 1996. was observed in the 20-29 and 40-49 year old groups (Figure 3). The ELISA test showed a $57 \%$ sensitivity and $97.5 \%$ specificity as opposed to IFAT (routine test used for LVA diagnosis by National Institute of Health of Colombia) (Table 2). Serological positivity with both tests (IFAT and ELISA) had an $80.4 \%$ agreement with the Montenegro test (Table 3). $2.7 \%$ of the people were simultaneously positive for $L$. chagasi and $T$. cruzi, indicating a possible crossed reaction or a mixed infection since individuals were encountered who were serologically positive for T. cruzi and negative for L. chagasi as determined by MST.

No differences were observed between positivity with respect to gender for T. cruzi nor for L. chagasi. Serologically reactive individuals did not show important clinical alterations compatible with AVL or Chagas' disease.

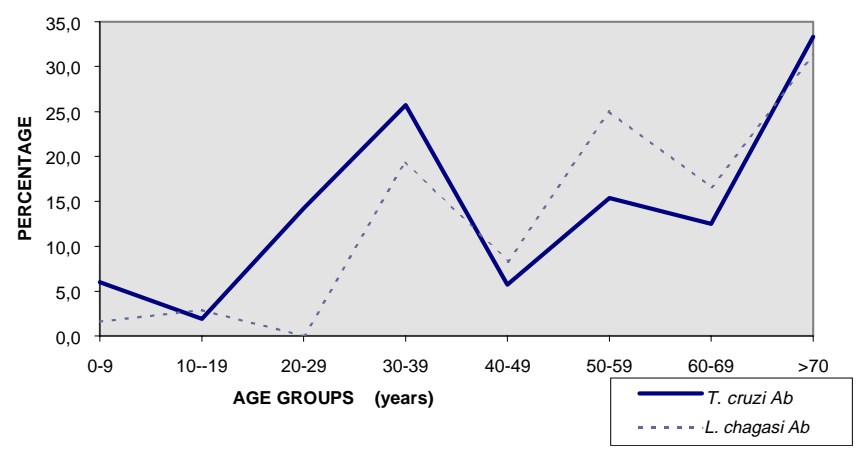

Fig. 3 - Seroprevalence by T. cruzi and L. chagasi by age groups.

Table 2

Comparison between serological tests for L. chagasi antibody detection. Coyaima, 1996

\begin{tabular}{lccc}
\hline & \multicolumn{3}{c}{ IFAT } \\
\cline { 2 - 4 } ELISA & POSITIVE & NEGATIVE & TOTAL \\
\hline POSITIVE & 12 & 11 & 23 \\
NEGATIVE & 9 & 422 & 431 \\
TOTAL & 21 & 433 & 454 \\
\hline
\end{tabular}




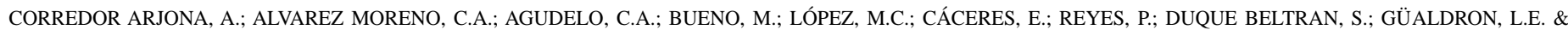
SANTACRUZ, M.M. - Prevalence of Trypanosoma cruzi and Leishmania chagasi infection and risk factors in a Colombian indigenous population. Rev. Inst. Med. trop. S. Paulo, 41(4): 229-234,1999.

\section{Housing and risk factors.}

1. $100 \%$ of the housing studied did not have a drinking-water supply, nor electric light and only housing included in the modification programme had excretion disposal facilities (latrines or fixed sanitary ware).

2. $50.6 \%$ of the houses presented earth floors and $90.1 \%$ bahareque (wooden-slat) walls.

3. $84.7 \%$ and $84.5 \%$ of the population did not use repellent nor mosquito netting respectively.

4. $86.3 \%$ recognized the vectors of the entities studied and $91 \%$ had seen wild reservoirs near their housing.

Table 4 describes the housing's principal characteristics and different risk factors for risks associated with $T$. cruzi and L. chagasi positivity. Statistically significant associations were encountered with vector

Table 3

Comparison of Serology and Montenegro Skin Test in L. chagasi infection detection. Coyaima, 1996

\begin{tabular}{cccc}
\hline $\begin{array}{c}\text { SEROLOGY } \\
\text { ELISA and/or } \\
\text { IFAT }\end{array}$ & $\begin{array}{c}\text { MONTENEGRO } \\
\text { TEST }\end{array}$ & FREQUENCY & $\begin{array}{c}\text { PERCENTAGE } \\
(\%)\end{array}$ \\
\hline+ & & & \\
+ & + & 11 & 3.7 \\
- & - & 10 & 3.0 \\
- & + & 49 & 16.5 \\
\hline TOTAL & - & 230 & 76.7 \\
\hline
\end{tabular}

Table 4

Relationship between housing characteristics and risk factors associated with T. cruzi and L. chagasi infection. Coyaima, 1996

ASSOCIATED
RISK FACTORS

\begin{tabular}{lllll}
\hline & $\mathbf{X}^{\mathbf{2}}$ & $\mathbf{P}$ & $\mathbf{X}^{\mathbf{2}}$ & $\mathbf{P}$ \\
Housing Modification & 2 & 0.15 & 5.32 & $\mathbf{0 . 0 2 *}$ \\
Wall Material & 0 & 0.99 & 2.52 & 0.11 \\
Flooring Material & 4.32 & $\mathbf{0 . 0 3 *}$ & 1.69 & 0.19 \\
Cement & & & & \\
Earth & & & & \\
Housing Fumigation & 0.51 & 0.47 & 0.53 & 0.96 \\
Use of mosquito netting & 0.01 & 0.93 & 0.56 & 0.45 \\
Possesion of animals & 0.01 & 0.93 & 0.48 & 0.49 \\
Possesion of dogs & 1.11 & 0.29 & 0.03 & 0.85 \\
Vector Identification & 5.65 & $\mathbf{0 . 0 1} *$ & 3.27 & 0.07 \\
\# inhabitants per house & 3.86 & $0.049 *$ & 0.43 & 0.5 \\
$<$ 2 inhabitants & & & & \\
> 2 inhabitants & & & & \\
\hline
\end{tabular}

presence and identification, number of inhabitants per house and flooring material in $T$. cruzi infection, whilst with $L$. chagasi only association with housing modification was found (Table 4).

\section{Entomology}

In the entomological study 42 Lutzomyia samples were found, which were identified as being L. cayannensis and L. longipalpis. L. longipalpis was found with greater frequency, a specie demonstrated to be the principal vector of $L$. chagasi in America. It is interesting to note that in spite of the low number of samples collected, various of these were found in the housing's walls, demonstrating intradomiciliary habits. In the majority of the homes farmyards with domestic animals (chicken, pigs) were found near the housing, a situation which increased the lutzomyias population, facilitating transmission. However, it is necessary to carry out vectorial studies in different seasons of the year to determine the months of greatest density.

Regarding the domestic reservoir study, the 22 dogs studied proved to be negative.

\section{DISCUSSION}

The $19 \%$ positivity found in the Montenegro Skin Test, is low when compared to results obtained in other zones of the country. In Córdoba $40 \%{ }^{29}$ was found and $51.2 \%$ in Cundinamarca ${ }^{9}$. However, this positivity is similar to that found in endemic regions of Africa ${ }^{26,28}$. As this test has high specificity and cutaneous leishmaniasis was not found in the zone studied, the allergic index, as well as the increase in positivity level with age, confirms active L. chagasi infection transmission.

L. chagasi serological prevalence was found to be similar to that observed in other seroepidemiological studies ${ }^{3,15,25}$. Serological values diminished over time whilst cellular immunity measured by Montenegro test remained positive ${ }^{28} .3 .0 \%$ of the T. cruzi and L. chagasi serologically positive but MST negative people could be explained by the possible crossed reactions between Leishmania and Trypanosoma as has been previously reported ${ }^{30}$. Additionally, when comparing these serological tests, ELISA and IFAT, with the Montenegro test high concordance is observed, $80.4 \%$, if compared with that published by BADARÓ et al., showed a $47 \%$ concordance in Brazil ${ }^{3}$.

L. chagasi infection in the majority of cases is not clinically manifested, which explains the high positivity in immunodiagnostic tests and the low presence of clinical cases of AVL. Thus, in this study, the positive people were not found to be ill and showed that they had not previously presented a picture compatible with AVL. However, it must not be forgotten that infected patients do not present the disease, thanks to the immune system's efficient action; but, once this system is altered Leishmania behaves as an opportunistic parasite as is shown in AIDS patients, in the world's different endemic zones ${ }^{1,2}$.

If the IFAT is considered to be the gold-standard, it is seen that ELISA has low sensitivity and high specificity for detecting L. chagasi antibodies as has been reported by other authors ${ }^{20,22}$.

When comparing positivity by gender, no difference was shown in any age group, which suggests that the exposure risk is equal amongst women and men. 


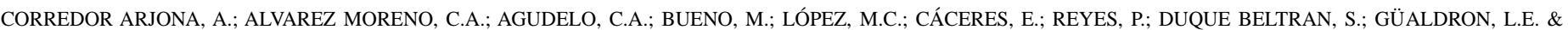

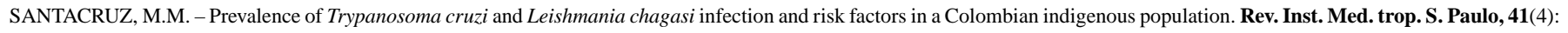
229-234,1999.

The $T$. cruzi positivity found indicates its active transmission in the region. Even though it is true that the crossed reaction with $L$ chagasi can explain some seropositives, $6 \%$ were only positive for $T$. cruzi. This figure is low when compared to highly endemic Colombian regions where a $26 \%$ positivity has been found ${ }^{11}$. However, to evaluate the problem's real magnitude, it is necessary to do further serological studies and to carry out electrocardiographic evaluation on positive individuals.

No correlation between housing modification and T. cruzi infection was found, whilst in L. chagasi infection greater infection was observed in the modified houses. This could be attributed to the short time elapsed between the modification of the housing and this survey, which is not useful for measuring the impact of housing modification although it can be employed as baseline data for the long-term assessment of the housing modification program. Additionally a positive relationship between triatomine recognition and $T$. cruzi seropositivity was found.

In general, the studied area's socio-economic conditions are precarious constituting the principal risk factor in the transmission of AVL as well as of Chagas' disease.

\section{RESUMO}

\section{Prevalência da infecção por Trypanosoma cruzi e Leishmania chagasi e fatores de risco numa população indígena da Colômbia}

Este estudo foi realizado para obter a linha de base da epidemiologia da Leishmaniose Visceral Americana e da Doença de Chagas numa comunidade indígena, onde o governo está desenvolvendo um programa de melhoramento da habitação. A coleta de dados referentes aos fatores sócio-econômicos e do meio ambiente associados ao risco de transmissão de Leishmania chagasi e Trypanosoma cruzi foi feita por meio de respostas a questionário endereçado aos componentes acima mencionados. O inquérito foi realizado em 242 unidades domiciliárias (1440 indivíduos). Foi realizada a prova de Montenegro em 385 indivíduos e colhidas 454 amostras de sangue em papel de filtro, para pesquisar o teor de anticorpos contra L. chagasi por meio das técnicas de ELISA e IFI e o teor de anticorpos contra T. cruzi por meio de ELISA.

A prevalência sorológica foi de $8,7 \%$ para $T$. cruzi, 4,6\% e 5,1\% para $L$. chagasi por meio de IFI e ELISA, respectivamente. Ao se comparar estas duas provas foi encontrado que por meio de ELISA a sensibilidade e especificidade para detecção de anticorpos contra $L$. chagasi foi de $57 \%$ e $97 \%$ respectivamente. Os resultados da intradermoreação de Montenegro revelaram uma positividade de 19\%. Os resultados dos três testes de imunodiagnóstico mostraram uma prevalência da infecção por $L$. chagasi de $17,1 \%$. Além disso, $2,7 \%$ da população estudada apresentou reações sorológicas positivas para os dois parasitos, evidenciando uma possível reação cruzada. A soropositividade para $L$. chagasi e T. cruzi aumentou com a idade, e não houve associação com o gênero. Idade ( $\mathrm{p}<0,007)$, número de moradores $(\mathrm{p}<0,05)$, tipo de piso $(\mathrm{p}<0,03)$ e o reconhecimento do vetor $(\mathrm{p}<0,01)$ foram associados com a infecção por T. cruzi. Entretanto, na infecção por $L$. chagasi foi encontrada associação com a idade ( $<<0,007)$ e o melhoramento da habitação $(\mathrm{p}<0,02)$. Recomenda-se avaliar o impacto do programa de melhoramento da habitação sobre estas infecções parasitárias nesta comunidade num prazo longo.

\section{ACKNOWLEDGEMENTS}

The authors would like to thank Dr. Santiago Nicholls, the Instituto Nacional de Salud's subdirector of Epidemiology, Dra. Gloria Palma from the School of Medicine, Universidad del Valle for their technical assistance and Coyaima and the Tolima department's local health authorities for the logistical help provided when carrying out this work. This project was financed through an agreement between the Ministerio de Salud-Universidad Nacional de Colombia No. 000352/95.

\section{REFERENCES}

1. ALTES, J.; SALAS, A.; RIERA, M. et al. - Visceral leishmaniasis: another HIVassociated opportunistic infection? Report of eight cases and review of the literature. AIDS, 5: 201-207, 1991.

2. BADARÓ, R.; CARVALHO, E.M.; ROCHA, H.; QUEIROZ, A.C. \& JONES, T.C. - Leishmania donovani: an opportunistic microbe asociated with progressive disease in three immunocompromised patients. Lancet, 1: 647-649, 1986a.

3. BADARÓ, R.; JONES, T.C.; LORENÇO, R. et al. - A prospective study of visceral leishmaniasis in an endemic area of Brazil. J. infect. Dis., 154: 639-649, 1986 b.

4. BARLETT, A. \& BIDWELL, D.E. - Enzyme immunoassays for parasitic diseases. Trans. roy. Soc. trop. Med. Hyg., 70: 98-106, 1976.

5. BOLETIN EPIDEMIOLÓGICO DEL TOLIMA - Leishmaniasis visceral Tolima. Bol. Epidem. del Tolima, 1: 1 - 15, 1983.

6. CAMARGO, M.E. - Fluorescent antibody test for the serodiagnosis of American trypanosomiasis. Technical modification employing preserved culture forms of Trypanosoma cruzi in a slide test. Rev. Inst. Med. trop. S. Paulo, 8: 227-234, 1966.

7. CORREDOR, A.; CASTILlO, N.Y. \& GUERRERO, P. - Estudio serológico sobre la incidencia de la infección chagásica en los donantes de sangre del Hospital San Juan de Dios. Rev. Fac. Med. (Bogotá), 33: 833-886, 1965.

8. CORREDOR, A. \& LÓPEZ, M.C. - Detección de anticuerpos para T. cruzi en papel de filtro por ELISA. Biomédica (Bogotá), 7: 83, 1987.

9. CORREDOR, A.; GALLEGO, J.F.; TESH, R.B. et al. - Epidemiology of visceral leishmaniasis in Colombia. Amer. J. trop. Med. Hyg., 40: 480-486, 1989.

10. CORREDOR,A.; SANTACRUZ, M.; GÓMEZ, S.Y. \& GUATAME, L. - Distribución de los triatominos domiciliados en Colombia. Bogotá, Instituto Nacional de Salud, 1990.

11. CORREDOR, A. - Situación epidemiológica de la tripanosomiasis americana en Colombia. Curso taller nacional de la enfermedad de Chagas. Bucaramanga, CINTROP, 1993.

12. DANE - Información censo 93. Santa Fé de Bogotá, DANE, 1995

13. DEAN, A. - Epi Info V. 6.04. Atlanta, Centers for Diseases Control and Prevention (CDC), 1996.

14. DE SOUZA, S.L. \& CAMARGO, M.E. - The use of filter paper blood smears in a practical fluorescent test for American trypanosomiasis serodiagnosis. Rev. Inst. Med. trop. S. Paulo, 8: 255-258, 1966.

15. EL-HASSAN, A.M.; ZIJLSTRA, E.E.; ISMAEL, A. \& GHALIB, H.W. - Recent observations on the epidemiology of Kala-azar in the eastern and central states of the Sudan. Trop. geogr. Med., 47: 151-156, 1995.

16. GAST GALVIS, A. - Primer caso de leishmaniosis visceral en Colombia. An. Soc. Biol. Bogotá, 1: 124, 1944. 


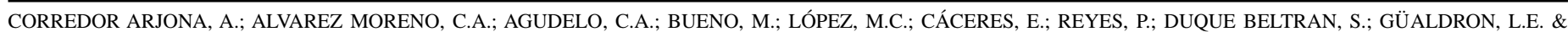
SANTACRUZ, M.M. - Prevalence of Trypanosoma cruzi and Leishmania chagasi infection and risk factors in a Colombian indigenous population. Rev. Inst. Med. trop. S. Paulo, 41(4): $229-234,1999$.

17. GÓMEZ, V.A. - Comunicación preliminar sobre dos casos de leishmaniasis visceral. Rev. Fac. Med. (Bogotá), 28: 163-167,1960.

18. GUHL, F.; CANOSA, A.; RUIZ, G. \& SÁNCHEZ, N. - Estudio serológico sobre la incidencia de donantes chagásicos en cuatro bancos de sangre de la ciudad de Bogotá. Rev. lat. amer. Microbiol., 21:225-227, 1979.

19. GUHL, F.; GARCIA, M.; CHING, R. et al. - Enfermedad de Chagas transfusional en Colombia. Trib. méd. (Bogotá), 91: 129-136, 1995.

20. HARITH, A.E.; KOLK, A.H.; KAGER, P.A. et al. - Evaluation of a newly developed direct agglutination test (DAT) for serodiagnosis and sero-epidemiological studies of visceral leishmaniasis: comparison with IFAT and ELISA. Trans. roy. Soc. trop. Med. Hyg., 81: 603-606, 1987.

21. INSTITUTO GEOGRAFICO AGUSTÍN CODAZZI - Atlas de Colombia. Santa Fé de Bogotá, CD ROM, 1993.

22. MENGISTU, G.; AKUFFO, H.; FEHNIGER, T.E.; NEGESE, Y. \& NILSEN, R. Comparison of parasitological and immunological methods in the diagnosis of leishmaniasis in Ethiopia. Trans. roy. Soc. trop. Med. Hyg., 86: 154-157, 1992.

23. MINISTERIO DE SALUD, REPUBLICA DE COLOMBIA - Leishmaniasis. Guia integral de manejo. Bogotá, 1994. p. 9-36.

24. MORENO, J. - Estudio preliminar de un foco de tripanosomiasis en el municipio de Coyaima, Tolima. In: REUNIÓN DE INVESTIGADORES DE MALARIAY OTRAS ENFERMEDADES TROPICALES, 2., Colombia, Ministerio de Salud, Dirección de Campañas Directas OPS/OMS, 1991. p.71.
25. OZBEL, Y.; TURGAY, N.; OZENSOY, S. et al. - Epidemiology, diagnosis and control of leishmaniasis in Mediterranean region. Ann. trop. Med. Parasit., 89(suppl.1): 89-93, 1995.

26. SCHAEFER, K.-U.; KURTZHALS, J.A.L.; KAGER, P.A. et al. - Studies on the prevalence of leishmanin skin test positivity in the Baringo District, Rift Valley, Kenya. Amer. J. trop. Med. Hyg., 50: 78-84, 1994.

27. SHIDDO, S.A.; ADEN, M.; AKUFFO, H.O. et al. - Visceral leishmaniasis in Somalia: prevalence of markers of infection and disease manifestations in a village in an endemic area. Trans. roy. Soc. trop. Med. Hyg., 89: 361-365, 1995a.

28. SHIDDO, S.A.; AKUFFO, H.O.; MOHAMED, A.A. et al. - Visceral leishmaniasis in Somalia: prevalence of leishmanin-positive and seropositive inhabitants in an endemic area. Trans. roy. Soc. trop. Med. Hyg., 89: 21-24, 1995b.

29. VÉLEZ, I.D.; TRAVI, B.; GALLEGO, J. Y. et al. - Evaluación ecoepidemiológica de la leishmaniosis visceral en la comunidad indígena Zenú de San Andrés de Sotavento, Cordoba: primer paso para su control. Rev. Col. Ent., 21: 111-122, 1995.

30. VEXENAT, A.C.; SANTANA, J.M. \& TEIXEIRA, A.R.L. - Cross-reactivity of antibodies in human infections by the kinetoplastid protozoa Trypanosoma cruzi, Leishmania chagasi and Leishmania (Viannia) braziliensis. Rev. Inst. Med. trop. S. Paulo, 38: 177-185, 1996.

31. WORLD HEALTH ORGANIZATION - Chagas' disease: progress in research 19891990 tropical diseases. Geneva, WHO, 1991. p. 69-77.

Received: 14 October 1998

Accepted: 21 June 1999 


\title{
"IN VIVO” AND “IN VITRO" DEMONSTRATION OF HEMOGLOBIN C CRYSTALS IN NON-SPLENECTOMIZED PATIENTS
}

\author{
J.T. deARAÚJO(1),A.C. BATISSOCO(2) \& L. BODEMEIER(3)
}

\begin{abstract}
SUMMARY
We studied $12 \mathrm{Hb}$ C carriers: 4 homozygotic $\mathrm{Hb}$ CC and 8 heterozygotic. We observed the presence of free crystals in the peripheral blood of the homozygotes but in none of the heterozygotes. However, after incubation with $3 \% \mathrm{NaCl}$ we were able to detect crystals in the heterozygotes ( $\mathrm{Hb} \mathrm{AC}$ and $\mathrm{Hb} \mathrm{SC}$ ), and in the homozygotes ( $\mathrm{Hb} \mathrm{CC}$ ). In patient 04 (P04) less crystals formation occurred due to inhibition of the process by the presence of elevated levels of $\mathrm{Hb} F(12.2 \%)$. All the homozygotic patients had a splenomegaly of 3 to 6 fingerbreadths. We believe that the spleen wears off with time, thus allowing the passage of crystals to the peripheral blood. This finding might be associated with splenic insufficiency without a reduction of its dimensions. Finally, the finding of crystals in the peripheral blood permitted the diagnosis of $\mathrm{Hb}$ C obviating the need for electrophoresis.
\end{abstract}

KEYWORDS: Hemoglobin C; Crystal; Non-splenectomized

\section{INTRODUCTION}

In 1950 ITANO \& NEEL ${ }^{10}$ described a new hemoglobin and named it hemoglobin C (Hb C). In 1953 SPAET et al. ${ }^{16}$ described a second case and soon thereafter RANNEY et al. ${ }^{13}$ report the third one with the curious observation of many target red blood cells in the patient's peripheral blood smear.

DIGGS et al. ${ }^{6}$ in 1954 described intra-erythrocytic crystals in the peripheral blood of $\mathrm{Hb} \mathrm{C}$ bearers, thus emphasizing that target cells were in reality crystals of $\mathrm{Hb} \mathrm{C}$ and the presence of free rods identified as crystals also caught his attention.

The main defect of $\mathrm{Hb} \mathrm{C}$ is the substitution of the glutamic acid residue at position 6 of the $\mathrm{N}$-terminal of the beta chain by a lysine, whilst in sickle cell disease the presence of $\mathrm{Hb} \mathrm{S}$ is due to the substitution of this same residue by a valine.

This phenomenon explains the morphological variations of the erythrocytes: forming crystals in $\mathrm{Hb} \mathrm{C}$, and sickle cells in $\mathrm{Hb} \mathrm{S}$, thus yielding it possible to identify these two different diseases by simply looking at peripheral blood smears.

In our opinion, the red cells described by RANNEY et al. ${ }^{13}$ contained $\mathrm{Hb} \mathrm{C}$ crystals within them and were morphologically different from the ones seen in $\mathrm{Hb} \mathrm{E}$, thalassemia, and certain liver diseases which are real target cells. Based on our experience it is possible to identify wether an $\mathrm{Hb}$ is of the $\mathrm{C}$ or E type simply by analyzing peripheral blood smears using a common optical microscope. In $\mathrm{Hb} \mathrm{E}$, thalassemia, and certain liver diseases typical target cells can be seen which differ from the ones observed in $\mathrm{Hb}$ $\mathrm{C}$ were both intra and extra-erythrocytic crystals are found even with the spleen present. FABRY et $a l .^{7}$, mention that only in smears of splenectomized $\mathrm{Hb} \mathrm{C}$ patients can the crystals be seen, as these crystals would be all removed by the spleen. Therefore, when splenectomy is performed, the resistance of the splenic network certainly disappears and consequently liberates these crystals. It is also hypothesized that as the splenic network wears off with time, splenic function in $\mathrm{Hb} \mathrm{C}$ patients diminishes which leads to increasing amounts of the crystals in the peripheral blood with age. In sickle cell disease patients we know that fibrosis followed by splenic involution does occur, many times reducing the spleen to a single nodule. However, in patients homozygotic for $\mathrm{Hb} \mathrm{C}$, although a reduction in splenic size does not occur, the progressive decrease in function is a fact that explains the finding of crystals in peripheral blood.

ADACHI \& ASAKURA, $1979^{1}$ studied Hb C crystals using a concentrated fosfate buffer and were able to identify numerous intra and extraerythrocytic crystals of this hemoglobin in the blood of $\mathrm{Hb} \mathrm{C}$ carriers. FABRY et al., $1981^{7}$ performed the same study using a $3 \% \mathrm{NaCl}$ solution, and the resulting crystals were named by ROZENBERG ${ }^{14}$ as sickling for $\mathrm{Hb} \mathrm{C}$, in contrast to red cells containing $\mathrm{Hb} \mathrm{S}$.

Although both $\mathrm{Hb} \mathrm{C}$ and $\mathrm{Hb} \mathrm{S}$ arise from the African continent, SUTCHARITCHAN et al. ${ }^{15}$ performing molecular studies, were able to identify the $\mathrm{Hb} \mathrm{C}$ gene in Thailandese natives, thus demonstrating a nonAfrican origin for $\mathrm{Hb} \mathrm{C}$.

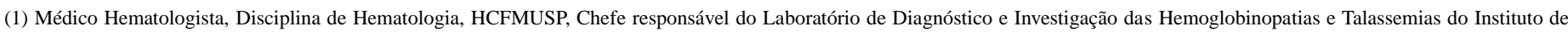
Medicina Tropical de São Paulo - HCFMUSP. Apoio: Fundação Faculdade de Medicina da USP, São Paulo, SP, Brasil.

(2) Farmacêutica-Bioquímica, aprimoranda do Laboratório de Diagnóstico e Investigação de Hemoglobinopatias e Talassemias do IMT-HCFMUSP, São Paulo, SP, Brasil.

(3) Biomédica do Laboratório de Diagnóstico e Investigação de Hemoglobinopatias e Talassemias do IMT-HCFMUSP, São Paulo, SP, Brasil.

Correspondence to: Prof. Dr. João Targino de Araújo, Instituto de Medicina Tropical de São Paulo, Av. Dr. Enéas de Carvalho Aguiar 470, 05403-000 São Paulo, SP, Brasil. 


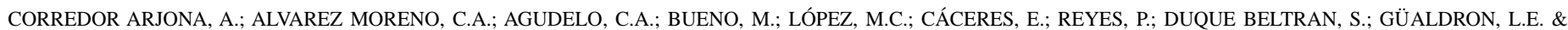
SANTACRUZ, M.M. - Prevalence of Trypanosoma cruzi and Leishmania chagasi infection and risk factors in a Colombian indigenous population. Rev. Inst. Med. trop. S. Paulo, 41(4): 229-234,1999.

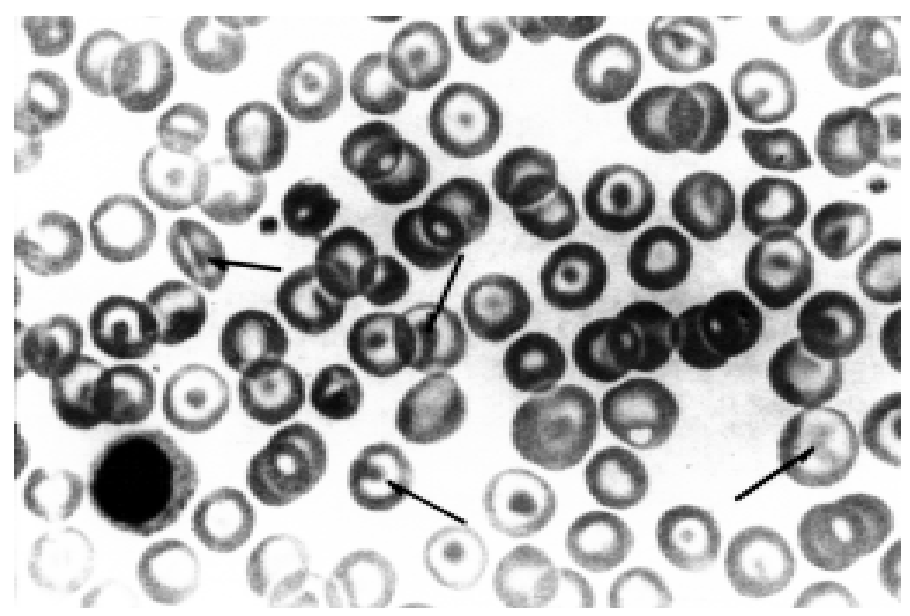

Fig. 1 - Hemoglobin C crystals in different erythrocytes, resembling target cells.

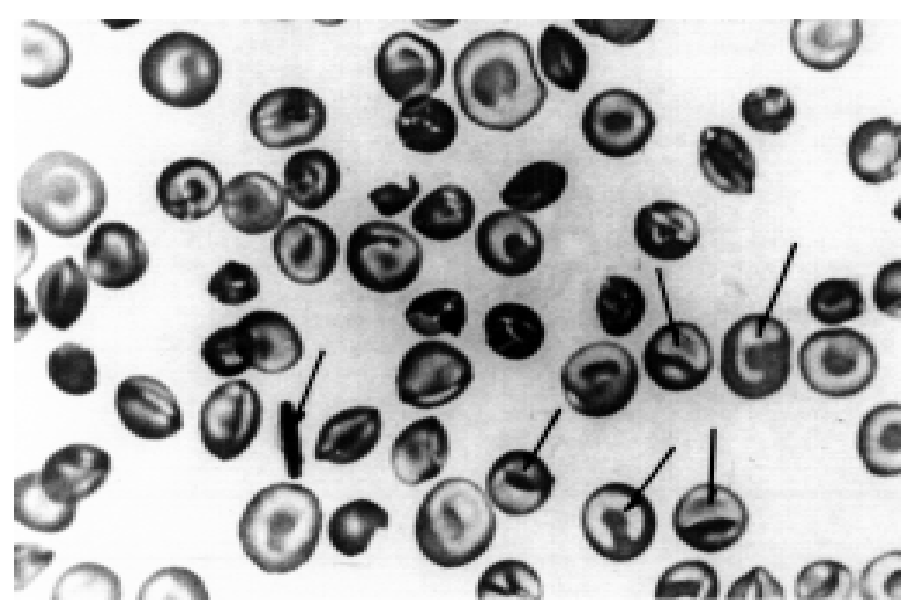

Fig. 2 - "In vitro" demonstration of tetrahedrical crystals of $\mathrm{Hb}$ CC in the peripheral blood of non-splenectomized patients. Arrows indicate one crystal out of erythrocyte and many crystals inside erythrocytes.

The incidence of $\mathrm{Hb} \mathrm{C}$ is 17 to $28 \%$ in Western Africa, in the vicinities of Northern Ghana. Up to the present date, no reasonable explanation accounts for this high occurrence ${ }^{17}$.

In Brazil, ARAUJO et al. ${ }^{3}$, reported an incidence of 0.6 to $1.0 \%$ of $\mathrm{Hb}$ $\mathrm{C}$ by means of crystals demonstration. He also described rare cases of $\mathrm{Hb}$ $\mathrm{C}$ in Italian and Portuguese descendants.

\section{METHODS AND MATERIALS}

During our analysis we identified 4 non-splenectomized carriers of $\mathrm{Hb} \mathrm{CC}, 4$ of $\mathrm{Hb} \mathrm{AC}$, and also 4 of Hb SC. We studied Hb C crystals in all the carriers, both after incubation with a phosphate buffer and a $3 \% \mathrm{NaCl}$ solution.

We also analyzed 50 normal blood samples as a negative control for the crystals.

The blood samples were collected with anticoagulant (EDTA), washed 3 times in saline, hemolysed to a $10 \mathrm{~g} \%$ hemoglobin concentration, and then analyzed by $\mathrm{pH} 8.6$ cellulose acetate electrophoresis, and $\mathrm{pH} 6.2$ agar gel. The fractions were measured after elution ${ }^{15}$, and $\mathrm{Hb} \mathrm{F}$ was quantitated by the Betke method ${ }^{5}$.

In order to demonstrate the crystals, we used a hypertonic $3 \% \mathrm{NaCl}$ solution, and also a phosphate buffer with a $\mathrm{pH}$ of 7.4 and $1.8 \mathrm{M}^{9}$.

The technique consisted of placing one drop of total blood and 2 drops of the $3 \% \mathrm{NaCl}$ solution 7 in a test tube and then incubating at $37^{\circ} \mathrm{C}$ for 4 hours. An identical procedure was performed using the phosphate buffer with a $\mathrm{pH}$ of 7.4 and $1.8 \mathrm{M}^{9}$.

The blood smears were stained with the Leishman method, and the crystals could be easily identified with the common optical microscope (Figure 1).

\section{RESULTS}

In the 50 samples of normal donors (negative controls) no intra or extra-erythrocytic crystals formation was observed.

The highest amount of crystals formation was seen in the homozygotics for $\mathrm{Hb} \mathrm{C}$, whilst the lower amount occurred in the heterozygotes for $\mathrm{Hb} \mathrm{AC}$. An amount of crystals intermediate between $\mathrm{Hb} \mathrm{CC}$ and $\mathrm{Hb}$ AS was found in the Hb SC cases (Fig. 1 and Fig. 2).

Also, a lower amount of crystals was present in those homozygotes for $\mathrm{Hb} \mathrm{C}$ that had higher levels of Fetal $\mathrm{Hb}$ (Table 1).

Table 1

Concentration of hemoglobin in both states homozygotic and heterozygotic,

and the presence of crystals

\begin{tabular}{|c|c|c|c|c|c|}
\hline & & $\% \mathrm{Hb} \mathrm{A}$ & $\% \mathrm{Hb} \mathrm{C}$ & $\% \mathrm{Hb} \mathrm{S}$ & $\% \mathrm{Hb}$ Fetal \\
\hline P1 & $\mathrm{Hb} \mathrm{CC}$ & & 98.7 & & 1.3 \\
\hline P2 & $\mathrm{Hb} \mathrm{CC}$ & & 98.3 & & 1.7 \\
\hline P3 & $\mathrm{Hb} \mathrm{CC}$ & & 98.4 & & 1.6 \\
\hline P4 & $\mathrm{Hb} \mathrm{CC}$ & & 77.8 & & 12.2 \\
\hline P5 & $\mathrm{Hb} \mathrm{AC}$ & 58.8 & 40.0 & & 1.2 \\
\hline P6 & $\mathrm{Hb} \mathrm{AC}$ & 57.8 & 40.6 & & 1.6 \\
\hline P7 & $\mathrm{Hb} \mathrm{AC}$ & 58.9 & 39.8 & & 1.3 \\
\hline P8 & $\mathrm{Hb} \mathrm{AC}$ & 58.5 & 40.1 & & 1.4 \\
\hline P9 & $\mathrm{Hb} \mathrm{SC}$ & & 45.5 & 51.1 & 3.4 \\
\hline P10 & $\mathrm{Hb} \mathrm{SC}$ & & 48.9 & 50.3 & 0.8 \\
\hline P11 & $\mathrm{Hb} \mathrm{SC}$ & & 48.3 & 51.0 & 0.8 \\
\hline P12 & $\mathrm{Hb} \mathrm{SC}$ & & 44.6 & 54.5 & 0.9 \\
\hline
\end{tabular}

Visualization of the crystals was better with the phosphate buffer at $\mathrm{pH} 7.4$ and $1.8 \mathrm{M}$ than with the $3 \% \mathrm{NaCl}$ solution.

The concentration of $\mathrm{Hb} \mathrm{C}$ measured by electrophoresis was of 30 to $40 \%$ for AC heterozygotes and of 40 to $50 \%$ for the SC. As for the homozygotes the concentration of $\mathrm{Hb} \mathrm{C}$ was of $98 \%$ with the remaining $2 \%$ consisting of Fetal $\mathrm{Hb}$, excepting those cases where there is an increase in $\mathrm{Hb} \mathrm{F}$ which reaches a concentration of $12.2 \%$ (Fig. 3). 


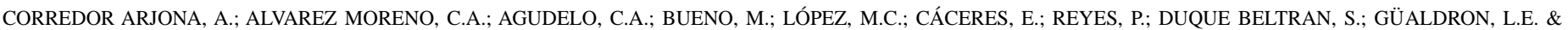

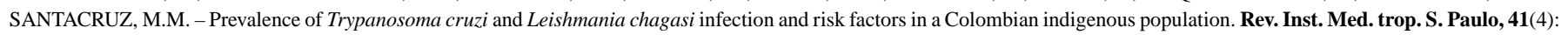
229-234,1999.

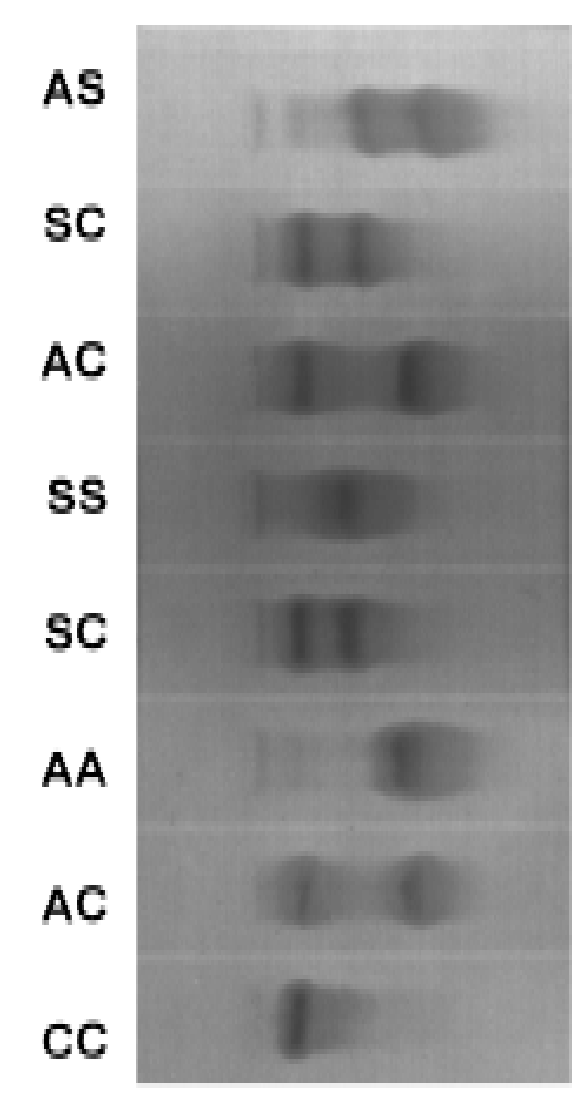

Fig. 3 - Hemoglobin electrophoresis by pH 8.6 agar gel demonstrating the differences in mobility of the hemoglobin fraction.

\section{DISCUSSION}

The spleen's clearing function, also known as "culling", refers to the organ's capacity of removing aged, dysmorphic, deformed, agglutinated, antibody or complement coated erythrocytes, and erythrocytic corpuscles (or bodies) $^{11}$.

This is the reason why a normal spleen would remove any free $\mathrm{Hb} \mathrm{C}$ crystals occasionally present in the circulation. However, even a normal splenic function might permit a few crystals containing erythrocytes to reach the circulation, and this accounts for the finding of these crystals in the peripheral blood of homozygotic $\mathrm{Hb} \mathrm{C}$ carriers.

When an individual undergoes splenectomy, the peripheral blood may show red cells with crystals similar to sickling forms, free crystals, and also Heinz and Howell-Jolly bodies ${ }^{11}$.

DIGGS et al. ${ }^{6}$ in 1954 , and posteriorly FABRY et al., $1981^{7}$ demonstrated the presence of $\mathrm{Hb} \mathrm{C}$ crystals in the peripheral blood of splenectomized and non-splenectomized patients. This is probably due to the fact the splenic network is many times unable to retain all the red cells with crystals, thus permitting their identification in the peripheral blood.

ROZENBERG $^{14}$, using photographs, demonstrated the presence of crystals in the peripheral blood of individuals with $\mathrm{Hb} \mathrm{C}$, and also confirmed the presence of these in the non-splenectomized carriers of $\mathrm{Hb} \mathrm{C}$ by means of the $3 \% \mathrm{NaCl}$ solution technique.

At our laboratory, we routinely examine the peripheral blood smears without prior knowledge of the diagnosis. In all cases, the crystals allowed us to identify the smears as proceeding from $\mathrm{Hb} \mathrm{C}$ patients, which was further confirmed by electrophoresis. Due to this fact, we concluded that the spleen is unable to retain all the crystals containing red cells or even the free crystals (Figure 2). We believe that over time, as the spleen retains the crystals of $\mathrm{Hb} \mathrm{C}$ the network becomes insufficient and thus allows the crystals to appear in the peripheral blood.

The spleen undergoes regression in sickle cell disease, in contrast to homozygotic $\mathrm{Hb} \mathrm{C}$ disease where the spleen remains enlarged, and no regression occurs. This does not mean, however, that damage due to crystals deposition does not occur. In fact, the crystals can be seen in simple X-Rays of the spleen.

Also, lower amounts of crystals are formed when comparing patients with $\mathrm{Hb} \mathrm{C}$ that present with high levels of Fetal hemoglobin in relation to those with normal levels.

HIRSCH et $_{\text {al }}{ }^{8}$ demonstrated that $\mathrm{Hb} \mathrm{F}$ inhibits the crystallization of $\mathrm{Hb} \mathrm{C}$ when compared to $\mathrm{Hb} \mathrm{A}$. The same is true for $\mathrm{A}^{2}\left(\alpha^{2} \delta^{2}\right)$ although to a lesser extent than $\mathrm{Hb} F\left(\alpha^{2} \gamma^{2}\right)$. These authors performed a study comparing the inhibitory potentials of the gama $(\gamma)$ delta $(\delta)$ chains. These chains both differ from the beta $(\beta)$ chain at 12 substitution sites, whilst having 4 residues in common located at positions $9,50,22$, and 87 . The two former residues are probably not responsible for the phenomenon, as they involve substitutions exhibiting similar proprieties. Position 22, however, although a common point in both gama $(\gamma)$ and delta $(\delta)$ chains, involves different substitutions. The gama $(\gamma)$ chain posseses an Asp substituting a Glu, whilst at the delta $(\delta)$ chain the Glu is substituted by a Val. We are left with position 87 were Thr is substituted for Gli in both the gama $(\gamma)$ and delta $(\delta)$ chains, and is therefore responsible for the crystallization of $\mathrm{Hb} \mathrm{C}$. In addition, this is the same residue that inhibits the polymerization of $\mathrm{Hb} \mathrm{S}$ by $\mathrm{Hb} \mathrm{A}^{2}$ and $\mathrm{Hb} \mathrm{F}^{8}$.

$\mathrm{Hb}$ Lepore-Washington originates from a mutation where a fusion between the beta and delta chains occurs, with substitution of only 6 residues. The resulting $\mathrm{Hb}$ is also able to inhibit $\mathrm{Hb} \mathrm{C}$ crystals formation albeit in lesser degrees if compared to $\mathrm{Hb} \mathrm{A}^{2}$ and $\mathrm{Hb} \mathrm{F}$. Consequently, this observation suggests that the Gli 87 residue is in fact responsible for the inhibition of $\mathrm{Hb} \mathrm{C}$ crystals formation. Nevertheless, in agreement with HIRSCH et al. ${ }^{8}$, the varied intensities of inhibition among the different hemoglobins enable us to conclude that there may be two possible explanations: the first is that this variation is probably due to the differences in hemoglobin molecular conformations, and the second is that residue 87 is not the only culprit. In this case, the other residues located between positions 88 and 146 might merit consideration.

Therefore, Fetal $\mathrm{Hb}$ with the $\gamma$ Gli 87 residue partially inhibits $\mathrm{Hb} \mathrm{C}$ crystallization, whilst $\mathrm{Hb} \mathrm{S}$ speeds up the process. This fact definetely demonstrates the existence of intra-erythrocytic crystals in the oxygenated form of the red blood cells of Hb SC individuals. Hb S might speed up crystallization due to the fact the phosphate buffer renders it insoluble?

The best visualization of the crystals occurred with the $1.8 \mathrm{M}$ 


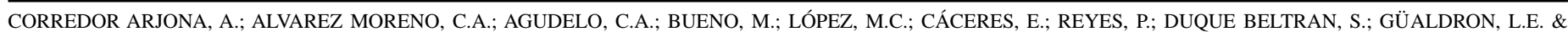
SANTACRUZ, M.M. - Prevalence of Trypanosoma cruzi and Leishmania chagasi infection and risk factors in a Colombian indigenous population. Rev. Inst. Med. trop. S. Paulo, 41(4): 229-234,1999.

phosphate buffer at a $\mathrm{pH}$ of 7.4 using the common optical microscope, due to the fact $\mathrm{Hb} \mathrm{C}$ is less soluble than $\mathrm{Hb} \mathrm{A}$ in these conditions.

\section{RESUMO}

\section{Cristais de hemoglobina C demonstráveis "in vivo" e "in vitro" em pacientes não esplenectomizados}

Estudamos 12 pacientes portadores de $\mathrm{Hb} \mathrm{C}$, sendo 4 homozigotos $\mathrm{Hb} \mathrm{CC}$ e 8 heterozigotos.

Observamos a presença de cristais livres no sangue periférico dos homozigotos e nenhum nos heterozigotos. Quando incubamos com $\mathrm{NaCl}$ $3 \%$, detectamos cristais quer nos heterozigotos, $\mathrm{Hb} \mathrm{AC}$ e $\mathrm{Hb} \mathrm{SC}$, quanto nos homozigotos, Hb CC. No paciente 4 (P04) houve menor formação de cristais devido a inibição pela $\mathrm{Hb}$ Fetal que se encontrava aumentada $(12,2 \%)$.

Todos os pacientes homozigotos mostraram esplenomegalia de 3 a 6 dedos. Emitimos a hipótese de que ocorra no baço um desgaste com o progredir da idade, permitindo a passagem dos cristais para o sangue periférico. Este fato poderia estar associado a uma insuficiência esplênica sem redução do baço.

A presença dos cristais no sangue periférico permitiu o diagnóstico de $\mathrm{Hb} \mathrm{C}$ mesmo sem a realização da eletroforese de $\mathrm{Hb}$.

\section{REFERENCES}

1. ADACHI, K. \& ASAKURA, T. - The solubility of sickle cell and non sickle hemoglobin in concentrate phosphate buffer. J. biol. Chem., 254: 4079-4084, 1979.

2. ARAÚJO, J.T. de - Hemoglobinas anormais em São Paulo. Métodos de estudo. Incidência. J. bras. Med., 9: 1264-1283, 1965.

3. ARAÚJO, J.T. de; RIBEIRO, V.S. \& ARAÚJO, R.A.T. - Hemoglobinopatias: aspectos moleculares, genéticos e clínicos. Rev. Hosp. Clín. Fac. Med. S. Paulo, 42: 260-266, 1964.

4. BETKE, K.; MARTI, H.R. \& SCHLICHT, I. - Estimation of small percentages of foetal haemoglobin. Nature (Lond.), 184: 1877-1878, 1959.
5. CHARACHE, S.; CONLEY, C.L.; WAUGH, D.F.; UGORETZ, R.J. \& SPURRELL, J.R. Pathogenesis of hemolytic anemia in homozygous hemoglobin C disease. J. clin. Invest., 46: 1795-1811, 1967.

6. DIGGS, L.W.; KRAUS, A.P.; MORRISSON, D.B. \& RUDNICKI, R.P.T. - Intraerythrocytic crystals in a white patient with hemoglobin $\mathrm{C}$ in the absence of other types of hemoglobin. Blood, 9: 1172-1184, 1954.

7. FABRY, M.E.; KAUL, D.K.; ROVENTOS, C. et al. - Some aspects of the pathophysiology of homozygous Hb CC erythrocytes. J. clin. Invest., 67: 1284-1291, 1981.

8. HIRSH, R.E.; LIN, M.J. \& NAGEL, R.L. - The inhibition of hemoglobin C and crystallization by haemoglobin F. J. biol. Chem., 263: 5936-5939, 1988.

9. HIRSH, R.E.; WITKOWSKA, H.E.; SHAFER, F. et al. - HbC compound heterozygotes [HbC/Hb Riyadh and $\mathrm{HbC} / \mathrm{Hb} \mathrm{N}$-Baltimore] with opposing effects upon $\mathrm{Hb} \mathrm{C}$ crystallization. Brit. J. Haemat., 97: 259-265, 1997.

10. ITANO, H.A. \& NEEL, J. - New inherited abnormality of hemoglobin. Proc. nat. Acad. Sci. (Wash.), 36: 613-617, 1950.

11. JAMRA, M. \& LORENZI, T. - Baço. Rio de Janeiro, Medsi, 1988.

12. NAOUM, P.C. - Hemoglobinopatias e talassemias. São Paulo, Sarvier, 1997.

13. RANNEY, H.M.; LARSON, P.L. \& McCORNACK JR., G.H. - Some clinical, biochemical and genetic observations on hemoglobin C. J. clin. Invest., 32: 1277, 1953.

14. ROZENBERG, G. - Microscopic Haematology: a practical guide for the laboratory. Sydney, Harwood Acad., 1996.

15. SUTCHARITCHAN, P.; NGO, H.; FUCHAROEN, S. et al. - The first report of Hb CE disease: diagnostic considerations posed by a $\beta^{\mathrm{c}}$ gene gone astray. In: CONGRESS OF THE INTERNATIONAL SOCIETY OF HAEMATOLOGY, 26, Singapore, 1996. (Int. J. Haemat., 64(suppl.1): S80, 1996).

16. SPAET, T.H.; ALWAY, R.H. \& WARD, G. - Homozygote type C hemoglobin. Pediatrics, 12: 483-490, 1953.

17. WILLIAMS, W.J.; BEUTLER, E.; ERSLEV, A.J. \& LICHTMAN, M.A.-Hematology. 4. ed New York, McGraw-Hill, 1990. p. 314.

Received: 28 May 1999

Accepted: 10 August 1999 